

\title{
Investigation of the weather conditions leading to large forest fires in the area around Athens, Greece
}

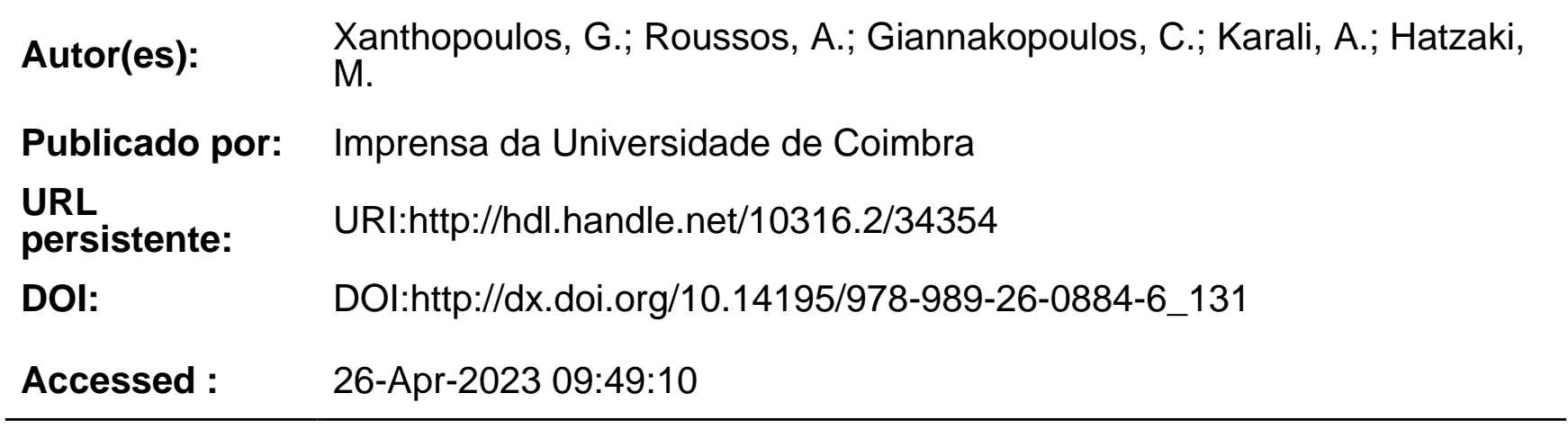

A navegação consulta e descarregamento dos títulos inseridos nas Bibliotecas Digitais UC Digitalis, UC Pombalina e UC Impactum, pressupõem a aceitação plena e sem reservas dos Termos e Condições de Uso destas Bibliotecas Digitais, disponíveis em https://digitalis.uc.pt/pt-pt/termos.

Conforme exposto nos referidos Termos e Condições de Uso, o descarregamento de títulos de acesso restrito requer uma licença válida de autorização devendo o utilizador aceder ao(s) documento(s) a partir de um endereço de IP da instituição detentora da supramencionada licença.

Ao utilizador é apenas permitido o descarregamento para uso pessoal, pelo que o emprego do(s) título(s) descarregado(s) para outro fim, designadamente comercial, carece de autorização do respetivo autor ou editor da obra.

Na medida em que todas as obras da UC Digitalis se encontram protegidas pelo Código do Direito de Autor e Direitos Conexos e demais legislação aplicável, toda a cópia, parcial ou total, deste documento, nos casos em que é legalmente admitida, deverá conter ou fazer-se acompanhar por este aviso.

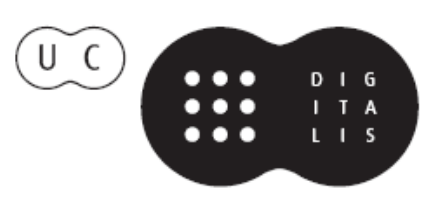




\section{ADVANCES IN}

Forest Fire

\section{RESEARCH}

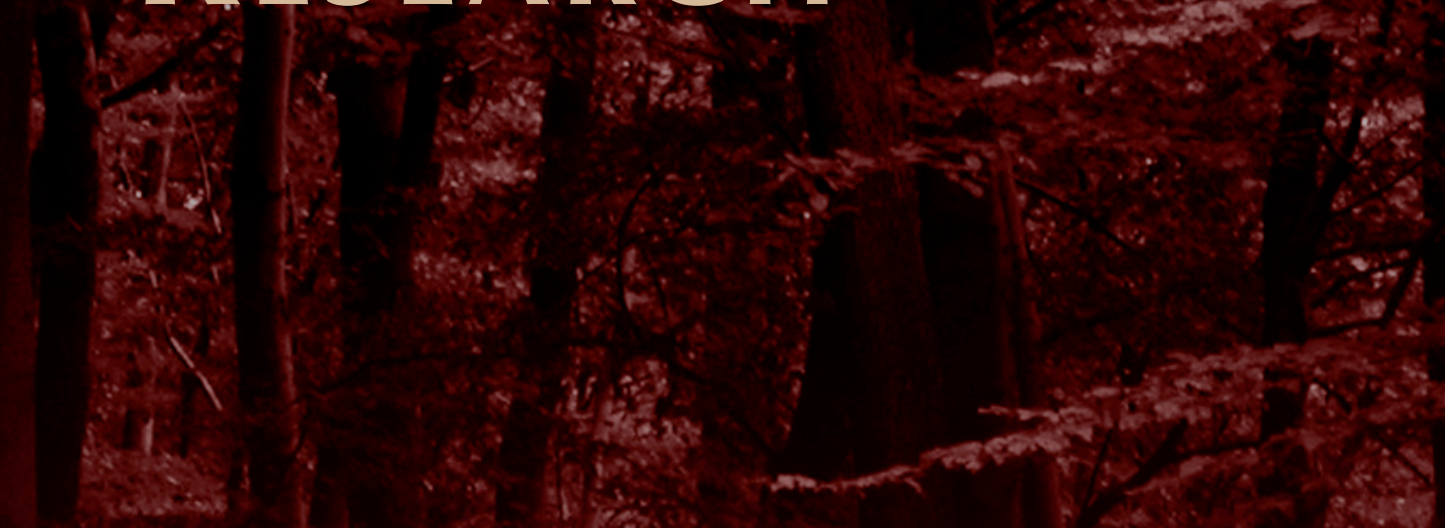

\section{DOMINGOS XAVIER VIEGAS}

\section{EDITOR}




\title{
Investigation of the weather conditions leading to large forest fires in the area around Athens, Greece
}

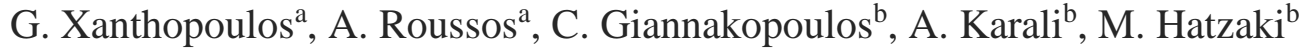 \\ ${ }^{a}$ Hellenic Agricultural Organization "Demeter". Institute of Mediterranean Forest Ecosystems and \\ Forest Products Technology.Terma Alkmanos, Ilisia, 11528, Athens, Greece.gxnrtc@fria.gr \\ ${ }^{b}$ Institute for Environmental Research and Sustainable Development,National Observatory of \\ Athens, Athens, Greece. I. Metaxa and V. Pavlou Street, Palaia Pendeli, 15236, Athens, Greece \\ cgiannak@meteo.noa.gr
}

\begin{abstract}
Large forest fires are of great concern in all fire prone countries. Understanding them and predicting the possibility for their occurrence can be very helpful for forest fire management. They usually occur under very adverse fire weather conditions so any investigation about them is sure to take this into consideration. The Fire Weather Index (FWI) of the Canadian Forest Fire Danger Rating System which enjoys very broad use not only in the vast forests of Canada but also in other parts of the world, is a composite index that represents fire weather conditions quite well. The study presented here is an investigation of the possibility to associate fire weather conditions, as captured by FWI, with the occurrence of large forest fires in the broader area around Athens, the capital of Greece. It is based on forest fire data from the Greek Fire Service for the 2003-2011 period, matched to FWI values for this period, calculated using gridded observation data from the ERA Interim data sets, that were interpolated using the Thin Plate Spline Technique in order to obtain high resolution $(1 \mathrm{~km})$ spatial analysis data. Correlations between FWI and burned area per fire proved to be very poor, precluding regression modelling, so an alternative analysis method was used in order to determine, according to the data for the study period, the minimum FWI above which it is possible for fires to exceed certain burned area thresholds.
\end{abstract}

Keywords: Fire Weather Index (FWI), large forest fires, Athens, Attica, Greece

\section{Introduction}

In the world of forest fire management the need for understanding and prediction of fire ignition probabilities and difficulty of control is the main reason for collecting fire statistics and for the development and use of fire danger rating systems. A significant number of such systems have been developed around the world, some having more global characteristics and use than others. Among them the Canadian Forest Fire Danger Rating System (CFFDRS) (Stocks et al. 1989, Forestry Canada Fire Danger Group, 1992) enjoys very broad use not only in the vast forests of Canada but also in other parts of the world including Europe where the System's Fire Weather Index (FWI) was evaluated favourably, among others, by Viegas et al. (1999) in comparison with four other methods of fire danger evaluation, and was adopted since 2007 at the EU level by the European Forest Fire Information System (EFFIS) of the Joint Research Centre of the European Commission (http://forest.jrc.ec.europa.eu/effis). The FWI was also evaluated favourably by Dimitrakopoulos et al. (2011) and by Karali et al. (2014) in Greece. Both these studies proposed FWI value classes for association with fire danger.

Although the FWI, according to most evaluation studies produces good predictions, its use can become much more meaningful for use in operational fire management if it is further investigated and calibrated to the specific fire conditions in the region where it is to be applied (e.g. Fogarty et al. 1998, Rainha and Fernandes 2002). Furthermore, it makes sense to examine if its predictions and utility can be improved by introducing additional information to the one already required for FWI calculation. 
The study presented here is an investigation of the fire weather conditions leading to large forest fires in the broader area around Athens, the capital of Greece. It was prompted by the operational need to tie the potential for such fires to FWI, in conjunction with the finding of studies like the one by Dimitrakopoulos et al. (2011) that the Fire Weather Index (FWI) while highly correlated to fire occurrence is only moderately correlated to burned area.

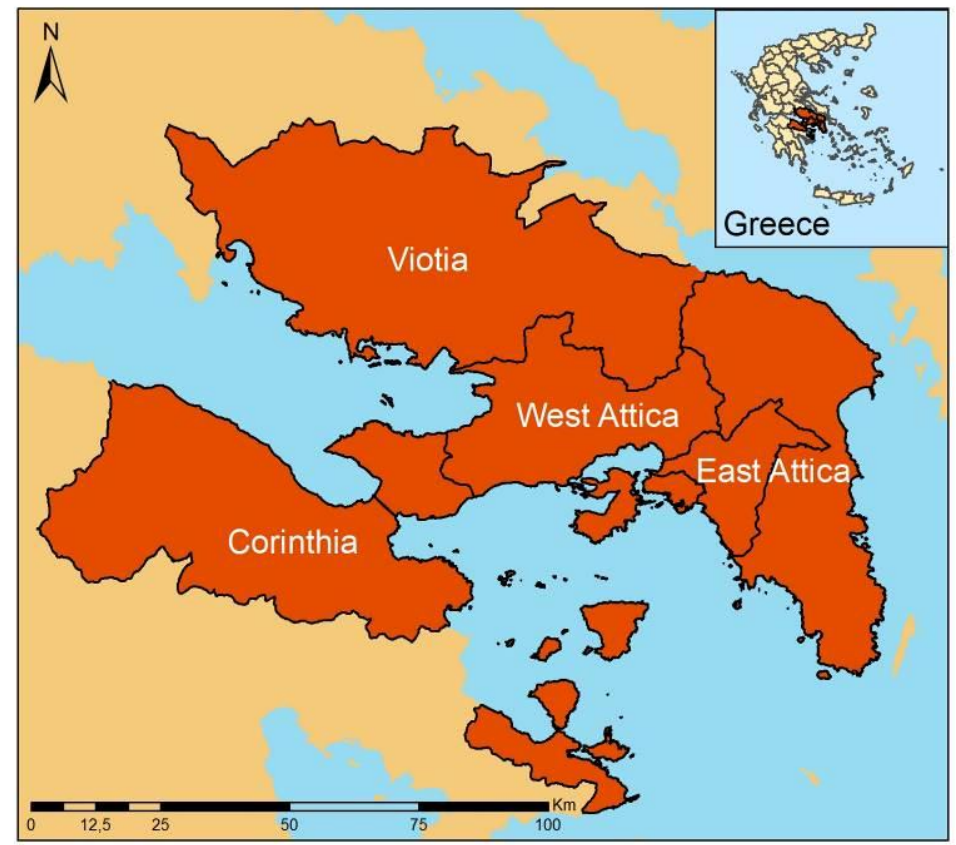

Figure 1. Map of the study area in Greece.

\section{Methods}

The study area covered the prefectures of East Attica, West Attica, Corinthia and Viotia (Figure 1). For this area forest fire data (dates, number of fires, burned area) for the 2003-2011 period, were obtained from the Greek Fire Service. Meteorological data were obtained from the ERA Interim data set (Dee et al. 2011) at a horizontal resolution of $0.75^{\circ}$ (approximately $82 \mathrm{~km}$ ). The gridded meteorological data were firstly interpolated from the $82 \mathrm{~km}$ grid to a high spatial resolution 1-km grid using the 3D Thin Plate Spline technique (Hutchinson 1998). Subsequently, the interpolated meteorological data were used to calculate FWI values for a particular representative site on Mount Hymettus near Athens. Forest fire data were then matched to the calculated FWI values. Further to this, each fire was associated with representative predawn water potential (WP) measurements for roughly the same day, collected during the 2003-2011 period on the same site on Mount Hymettus (Xanthopoulos et al. 2006). These WP measurements were carried out for three representative Mediterranean species: Pinus halepensis, Quercus coccifera and Cistus creticus. This trial aimed to examine if the drought experienced by the living forest plants can play an important role in the occurrence of large fires in addition to the influence of the current weather condition captured by the FWI.

\section{Analysis and results}

The total number of fires reported in the four prefectures in the period of interest reached 6,860 . They had burned a total area of 43,569 ha, roughly $5 \%$ of the study area. Some of them were identified as 
non forest fires (e.g. agricultural residue burning) and were dropped from the database. The rest of the fires were analyzed putting emphasis on the large fires that occurred in this time period.

The FWI for all days with fire, varied between 0.0001 and 102.92. On the day of the highest FWI (August 22, 2010) six fires were reported. Their burned area ranged between 0.05 and 7 ha. The maximum burned area for one fire was 17,500 ha. This historic fire started on August 21, 2009, under an FWI of 71.845 .

Focusing on large fires, a sub-sample of the data set was created with all fires having a burned area equal to or larger than 10 ha. The number of observations was 175. This smaller data set was examined in regard to the correlation of burned area with FWI. The Pearson correlation proved to be very low (0.133) and non-significant. The existence of the large 17,500 ha fire of August 2009 in the dataset was considered as a probable reason for this low correlation. However, even when this data point was removed $(\mathrm{N}=174)$, the correlation reached only 0.183 and became significant at the 0.05 level (2tailed). Obviously, these low correlations preclude any effort for predictive regression modelling. Figure 2 is a plot of the 174 point data set, after omission of the 17,500 ha fire.

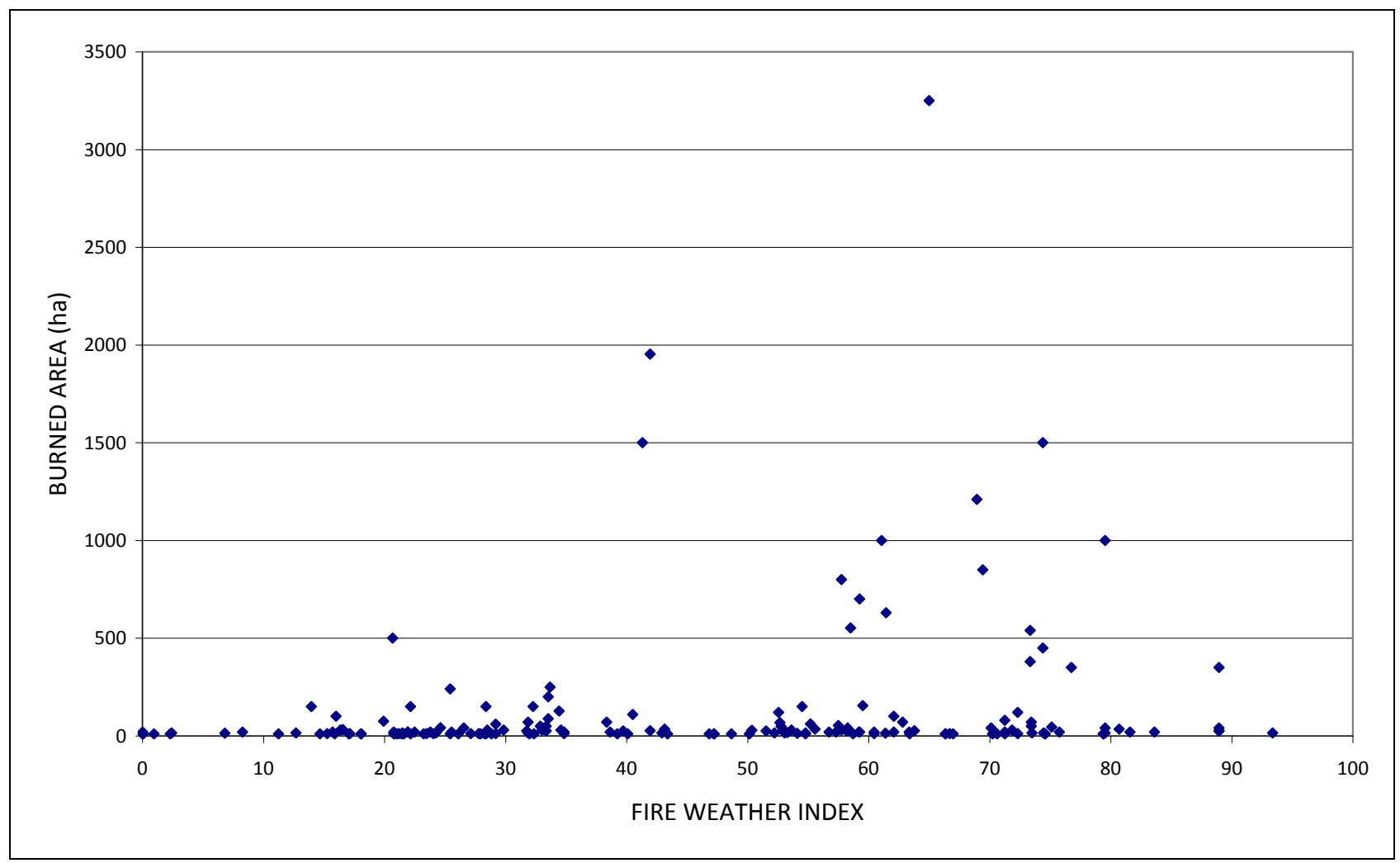

Figure 3. Plot of the Fire Weather Index versus the burned area of the 174 largest fires in the study region in the 2003-2011 period, omitting for scaling purposes the largest fire of 17,500 ha that occurred under a FWI of 71.845

The water potential data for the three species examined also had poor correlation with burned area. The same was true when the product of FWI with water potential was examined for correlation with burned area, so at this stage the WP data were not examined further.

These results illustrated the problem of the potential discrepancies between FWI and burned area and called for a different ad-hoc approach for analysing the data set in regard to large fires. This approach was as follows: selecting sub-samples of the database that included only the fires that burned an area larger than a specific threshold (ha), the minimum FWI and maximum FWI for each sub-sample were entered in a table (Table 1) and were also plotted against that threshold. 
Table 1. Number of fires, Minimum FWI, and Maximum FWI for subsets of the complete dataset that each included only the fires above a selected burned area threshold (ha).

\begin{tabular}{|c|c|c|c|}
\hline Burned Area Threshold (ha) & Number of fires & FWI Min & FWI Max \\
\hline 10 & 175 & 0,00705 & 93,37405 \\
\hline 20 & 100 & 0,01265 & 88,93933 \\
\hline 30 & 69 & 13,95373 & 88,93933 \\
\hline 40 & 56 & 13,95373 & 88,93933 \\
\hline 50 & 48 & 13,95373 & 88,93933 \\
\hline 60 & 44 & 13,95373 & 88,93933 \\
\hline 70 & 41 & 13,95373 & 88,93933 \\
\hline 80 & 36 & 13,95373 & 88,93933 \\
\hline 90 & 34 & 13,95373 & 88,93933 \\
\hline 100 & 34 & 13,95373 & 88,93933 \\
\hline 110 & 32 & 13,95373 & 88,93933 \\
\hline 120 & 31 & 13,95373 & 88,93933 \\
\hline 130 & 28 & 13,95373 & 88,93933 \\
\hline 150 & 28 & 13,95373 & 88,93933 \\
\hline 170 & 22 & 20,67158 & 88,93933 \\
\hline 200 & 22 & 20,67158 & 88,93933 \\
\hline 250 & 20 & 20,67158 & 88,93933 \\
\hline 300 & 19 & 20,67158 & 88,93933 \\
\hline 350 & 19 & 20,67158 & 88,93933 \\
\hline 400 & 16 & 20,67158 & 79,54018 \\
\hline 500 & 15 & 20,67158 & 79,54018 \\
\hline 600 & 12 & 41,3183 & 79,54018 \\
\hline 700 & 11 & 41,3183 & 79,54018 \\
\hline 800 & 10 & 41,3183 & 79,54018 \\
\hline 900 & 8 & 41,3183 & 79,54018 \\
\hline 1000 & 8 & 41,3183 & 79,54018 \\
\hline 1200 & 6 & 41,3183 & 74,38725 \\
\hline 1400 & 5 & 41,3183 & 74,38725 \\
\hline 1600 & 3 & 41,3183 & 74,38725 \\
\hline 1800 & 3 & 41,3183 & 74,38725 \\
\hline 2000 & 2 & 64,99238 & 71,84505 \\
\hline 3300 & 1 & 71,84505 & 71,84505 \\
\hline
\end{tabular}

As shown in table 1, 175 fires had each burned an area equal to or exceeding 10 ha $\left(\mathrm{N}_{10}=175\right)$. The minimum FWI value among these fires was 0.007 and the maximum FWI was 93.374. This means that a fire may reach or exceed 10 ha even at an FWI $=0.007$.

When setting the threshold at 20 ha the number of fires dropped to $\mathrm{N}_{20}=100$, the minimum FWI was 0.012 and the maximum FWI was 88.894. This means that even at this minimum FWI value a fire may exceed 20 ha. The smaller maximum FWI value in this subset means that a fire that occurred with an FWI of 93.374 and was included in the previous subset because it had burned over 10 ha, did not exceed the 20 ha threshold and was left out of this second subset.

The next subset with the threshold burned area set at 30 ha, had a minimum FWI of 13.95 and $\mathrm{N}_{30}=69$. The same minimum FWI remained for the next subsets until the threshold was set to 170 ha $\left(\mathrm{N}_{170}=\right.$ 22) and the minimum FWI became 20,672. 
Following the same logic, the plot of Figure 3 was created. It shows the minimum FWI thresholds that make it possible for fires to exceed initial attack capabilities and, as long as there is available fuel in their path, to become large or very large.

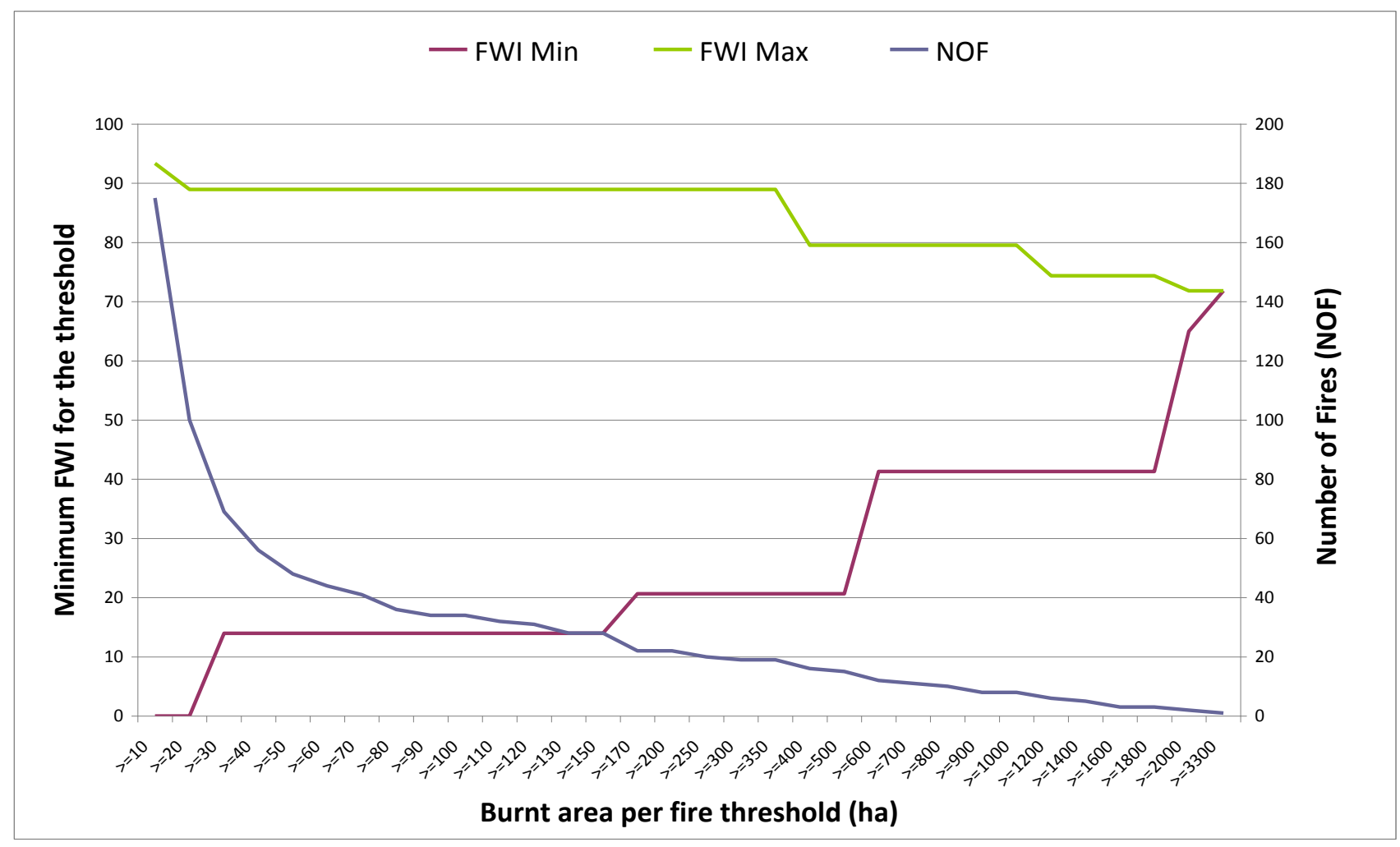

Figure 3. Minimum FWI that may allow forest fires to exceed certain burned area thresholds for the conditions (vegetation, firefighting resources, etc.) in the study area around Athens, in Greece.

\section{Discussion and conclusions}

The efforts spent looking for a mathematically expressed relation between FWI and burned area did not produce any results. This is in agreement with the conclusions of Dimitrakopoulos et al. (2011). It is clear that whereas fire ignition probabilities correlate reasonably well with the weather conditions as captured by FWI, things are quite different in regard to burned area. The varying capability of firefighting resources, temporally and spatially, is a significant factor affecting the evolution of each fire. The existence of fuel in the path of a fire is also another important factor that acts randomly on every fire depending on where it starts and on the direction of its spread. Further to the above, there are various sources of errors in the data set that may have added "noise" reducing correlations further. These sources of error are:

- Inaccuracy of reported burned area per fire by the Fire Service (it is called an estimate, not a measurement)

- Calculation of FWI over broad areas rather than based on the local conditions of each fire.

- Using one value of water potential per species (average of two measurements) from one location in Attica and from the closest available date to the date of the fire.

On the other hand, the alternative method of analysis used here, as shown in Table 1 and Figure 3, provides some thresholds that can be useful for setting mobilization levels according to predicted 
weather conditions and FWI, and also for guiding pre-fire positioning of firefighting resources and for supporting dispatching decisions in case of fire eruption. More specifically, it can be concluded that:

- If the FWI exceeds 0,01 fires exceeding 20 ha are possible.

- If the FWI exceeds 13,95 fires exceeding 30 ha are possible.

- If the FWI exceeds 13,95 fires exceeding 30 ha are possible.

- If the FWI exceeds 20,67 fires exceeding 170 ha are possible.

- If the FWI exceeds 41,32 fires exceeding 600 ha are possible.

- If the FWI exceeds 64,99 fires exceeding 2000 ha are possible.

- If the FWI exceeds 71,84 fires exceeding 3300 ha are possible.

\section{Acknowledgements}

The research reported here was carried out in the frame of a research project of the Institute of Mediterranean Forest Ecosystems and Forest Products Technology (IMFE\&FPT) titled "Investigation of the relation between the water potential of forest plants and forest fires", and a second project titled "Contribution to Fire Prevention in 2013-2014 using the INCA methodology". This latter project was funded by the Special Secretariat for Forests through the "Green Fund" of the Greek Ministry of Environment, Energy, and Climate Change.

\section{References}

Dee DP, Uppala SM, Simmons AJ, Berrisford P, Poli P, Kobayashi S, ... \& Vitart, F (2011) The ERAInterim reanalysis: Configuration and performance of the data assimilation system. Quarterly Journal of the Royal Meteorological Society 137(656), 553-597.

Dimitrakopoulos AP, Bemmerzouk AM, Mitsopoulos ID (2011) Evaluation of the Canadian fire weather index system in an eastern Mediterranean environment. Meteorological Applications 18(1), 83-93.

Fogarty LG, Pearce HG, Catchpole WR, Alexander ME (1998) Adoption vs. adaptation: lessons from applying the Canadian forest fire danger rating system in New Zealand. In Proceedings, 3rd International Conference on Forest Fire Research and 14th Fire and Forest Meteorology Conference, Luso, Coimbra, Portugal. (Ed. DX Viegas)pp. 1011-1028. (ADAI: Coimbra, Portugal).

Forestry Canada Fire Danger Group 1992. Development and structure of the Canadian Forest Fire Behavior Prediction System. Forestry Canada, Ottawa, ON. 63 p. Information Report ST-X-3.

Hutchinson MF (1998) Interpolation of rainfall data with thin plate smoothing splines - part II: analysis of topographic dependence. Journal of Geographic Information and Decision Analysis 2:152-167.

Karali A, Hatzaki M, Giannakopoulos C, Roussos A, Xanthopoulos G, Tenentes V (2014) Sensitivity and evaluation of current fire risk and future projections due to climate change: the case study of Greece, Nat. Hazards Earth Syst. Sci., 14, 143-153.

Stocks BJ, Lynham TJ, Lawson BD, Alexander ME, Wagner CV, McAlpine RS, Dube DE (1989) The Canadian forest fire danger rating system: an overview. The Forestry Chronicle 65(4), 258-265.

Van Wagner CE (1987) Development and structure of the Canadian Forest Fire Weather Index System. Canadian Forestry Service, Forestry Technical Report 35. Ottawa, Ontario, Canada.

Viegas DX, Bovio G, Ferreira A, Nosenzo A, Sol B (1999) Comparative study of various methods of fire danger evaluation in southern Europe. International Journal of Wildland Fire 9, 235-246.

Xanthopoulos G, Maheras G, Gouma V, Gouvas M (2006) Is the Keetch-Byram drought index (KBDI) directly related to plant water stress? In "Forest Ecology and Management", Vol. 234, Supplement 1, (Ed. DX. Viegas), p. 27 (abstract). (Elsevier Publishers, Amsterdam). Full text, in Proceedings of the $5^{\text {th }}$ International Conference on Forest Fire Research. November 27-30, 2006, Figueira da Foz, Portugal (on CD). 